\title{
Valuation of irrigation water in South-western Iran using a hedonic pricing model
}

\author{
Abdoulkarim Esmaeili $\cdot$ Zahra Shahsavari
}

Received: 17 March 2011/Accepted: 9 September 2011/Published online: 27 September 2011

(C) The Author(s) 2011. This article is published with open access at Springerlink.com

\begin{abstract}
Population growth, improved socioeconomic conditions, increased demand for various types of water use, and a reduction in water supply has created more competition for scarce water supplies leveling many countries. Efficient allocation of water supplies between different economic sectors is therefore very important. Water valuation is a useful tool to determine water price. Water pricing can play a major part in improving water allocation by encouraging users to conserve scarce water resources, and promoting improvements in productivity. We used a hedonic pricing method to reveal the implicit value of irrigation water by analyzing agricultural land values in farms under the Doroodzan dam in South-western Iran. The method was applied to farms in which irrigation water came from wells and canals. The availability of irrigation water was one of the most important factors influencing land prices. The value of irrigation water in the farms investigated was estimated to be $\$ 0.046$ per cubic meter. The estimated price for water was clearly higher than the price farmers currently pay for water in the area of study. Efficient water pricing could help the sustainability of the water resources. Farmers must therefore be informed of the real value of irrigation water used on their land.
\end{abstract}

Keywords Value of irrigation water - Agricultural land prices $\cdot$ Hedonic pricing method $\cdot$ Iran

A. Esmaeili $(\bowtie) \cdot$ Z. Shahsavari

Shiraz University, Shiraz, Iran

e-mail: esmaeili68@yahoo.com

\section{Introduction}

Water resources are necessary inputs to production in economic sectors such as agriculture (e.g., arable and nonarable land, aquaculture, commercial fishing, and forestry), industry (e.g., power generation) and tourism, as well as to household consumption (United Nations Environment Program (UNEP) 2005).

National policies aimed at allocating water resources among different sectors vary significantly between countries. Governments control water supplies in many countries. These countries typically do not allocate water on the basis of the economic efficiency but instead use other criteria such as fairness or equity. Due to many reasons (but especially to promote crops), governments tend to favor the agricultural sector. In Iran, the proportion of agricultural water in the total consumption of water is high. About $95 \%$ of usable water resources in Iran are allocated to the agricultural sector. Planning the optimal use of water for a country such as Iran that contains arid and semi-arid regions is therefore important. The low price of agricultural water and the subsidies provided by the government for using this resource results in a little incentive to conserve it or to refrain from growing water-intensive crops. The price of agricultural water is far below its economic value. Farmers often pay very little for agricultural water. A crucial factor that contributes to inefficient water allocation is the apparent lack of appropriate pricing of agricultural water.

Statistical analyses and studies revealed that one factor associated with water shortages and reduced water quality is high and inappropriate consumption of water. High consumption of water may be due to its low price or lack of knowledge about its true economic value. Many studies carried out by scholars using different methods to evaluate water economic value (Torell et al. 1990; Young 1996; 
Tarimo et al. 1998; Faux and Perry 1999; Doppler et al. 2002; Abu-Madi 2009). Among pricing methods, this is the appropriate valuation of water which, as a classic non-marketed resource, can seldom be assigned a justified market price (even for commodity use). Therefore, in most cases, an indirect, a non-marketed method is employed to calculate an accurate figure for the value of water (Young 1996).

The hedonic pricing method (HPM) is a specific valuation technique used to disaggregate the sale price of the bundled good (i.e., land property) to reveal its water component (Latinopoulos et al. 2004). The hedonic price model used in this study is an inductive approach. Inductive methods involve a process of reasoning from the particular to the general, or from real-world data to general relationships. Inductive methods involve observation of prices from water rights or land and water right transactions or responses to survey questionnaires (Young 2005). The implicit price of irrigation water can be revealed by hedonic analyses of sales of irrigated farm properties. The sale price of the bundled good-irrigated farm propertycan be disaggregated using hedonic analyses to reveal the implicit price paid for the water component of the transaction. Using hedonic analyses to estimate the value of water has the advantage of being based on market transactions rather than an analyst's estimates of crop yields, crop prices, fixed costs, and variable costs of production (Faux and Perry 1999).

The earliest example of a HPM applied to the valuation of irrigation water was by Milliman (1959) and Hartman and Anderson (1962). Torell et al. (1990) compared sales of irrigated and non-irrigated land to estimate the value of groundwater in the Southern High Plains in the USA. Results indicated that the water value component or sale transactions of irrigated farms ranged from 30 to $60 \%$ of farm sale prices dependent upon the particular state in the USA. Coelli et al. (1991) used a HPM to determinate the benefit of a water supply scheme in Western Australia. Mean per hectare values of the water supply scheme using this model was \$18.4. Xu et al. (1994) estimated a hedonic price function using agricultural land sales in six geographic regions covering Eastern Washington in the USA. They examined the value of variables which had effects on land sale prices. Faux and Perry (1999) applied a HPM to agricultural land sales in Malheur County (OR, USA) to reveal the implicit market price of water used for irrigation. The value of irrigation water in this location was estimated to be $\$ 0.009$ for one cubic meter on the least productive land irrigated, and up to $\$ 0.044$ per cubic meter on the most productive land. In a study by Latinopoulos et al. (2004), hedonic pricing was applied to a sample of irrigated and non-irrigated properties in Chalkidiki (a typical rural area in Greece). The value of irrigation water was estimated by disaggregating the total price of each parcel of land, obtained through a local survey. Results showed that the agricultural characteristics of the land (including availability of irrigation water) had a significant influence on land prices. The marginal value of water for irrigation in Chalkidiki was estimated to be $\$ 0.054$ for one cubic meter.

Poora et al. (2007) used a hedonic property value model to investigate the marginal implicit values of total suspended solids and dissolved inorganic nitrogen of water in the state of Maryland in the USA. Econometric results indicated that the marginal implicit prices associated with a change of $1 \mathrm{mg} / \mathrm{L}$ in total suspended solids and dissolved inorganic nitrogen were $\$ 1,086$ and $\$ 17,642$, respectively.

We attempted to apply a hedonic model to reveal the implicit value of irrigation water by analyses of agricultural land property values.

\section{Method}

One of the valuation environment resource methods is revealed preference methods, also known as indirect valuation methods, look for related or surrogate markets in which the environmental good is implicitly traded (Lancaster 1966). Information derived from observed behavior in the surrogate markets is used to estimate willingness to pay (WTP). WTP represents an individual's valuation of, or the benefits derived from, the environmental resource. Two such methods prevalent in the literature pertaining to environmental economics are the HPM and the travel cost method. These methods are suitable for valuing water resources that are marketed indirectly and therefore can only estimate their use (direct and indirect) values.

The HPM is based on Lancaster's characteristics theory of value (Lancaster 1966). This states that any good can be described as a bundle of characteristics and the levels these take, and that the price of the good is dependent upon these characteristics and their respective levels. It is commonly applied to variations in housing prices that reflect the value of local environmental resources. The price of a house will reflect its characteristics (i.e., number of bedrooms, number of bathrooms, size, schools in the neighborhood, crime level) in addition to local environmental resources (e.g., quality of ambient air, noise levels, aesthetic views, quantity or quantity of water) (Birol et al. 2006).

It follows that an implicit price exists for each of the characteristics and that an implicit marginal WTP (which represents an individual's valuation of the incremental unit of the environmental resource) can be identified statistically. An important assumption of the hedonic method is that regions are treated as a single land market (Freeman and Veeman 1993). It is also assumed that individuals have perfect information on all the alternative types of land available, and that they are free to choose any land plot 
within the market for production. Therefore, this method describes how prices of various highly differentiated land plots would be determined under conditions of perfect competition with the market in equilibrium. It may be unrealistic to assume that consumers are fully informed and have zero transaction costs, but this does not affect the validity of the HPM. Any errors due to imperfect information can affect all land prices uniformly so HPM is not biased. Markets that are not in equilibrium may introduce only random errors into the estimates of marginal WTP. However, if market forces are continually moving in one direction, then biased estimates of the marginal implicit prices may result (Veeman et al. 1994).

There are two stages to the hedonic property valuation model. The first stage involves estimating the hedonic price function whereby the price of a residential property is regressed on its characteristics to determine the value consumers place on the characteristics that comprise the differentiated good (Feenberg and Mills 1980). In different studies of the hedonic model, three forms are applied: linear, semi-log function, and $\log -\log$. A function-dependent variable $(p)$ is regressed on a set of characteristics $(x)$, including structural characteristics, neighborhood characteristics and environmental-water quality characteristics. These models of regression are:

$p=\beta_{0}+\sum_{k=1}^{k} \beta_{k} x_{k}$ (linear form)

$\ln p=\ln \beta_{0}+\sum_{k=1}^{k} \beta_{k} x_{k}$ (semi - log function form)

$\ln p=\ln \beta_{0}+\sum_{k=1}^{k} \beta_{k} \ln x_{k}(\log -\log$ form $)$

In these models, $p$ is the price of one hectare of land, $\beta_{0}-$ $\beta_{k}$ are the coefficients to be estimated, and $x_{k}$ are independent variables. Thus, for an environmental hedonic model, the first stage of the model estimates the marginal implicit prices of the specific environmental characteristics. This can then be used as the price variable in the second stage to estimate the demand equation for the characteristic (Poora et al. 2007). This research includes a stage-one analysis whereby measures of irrigation water quantity along with other structural and neighborhood farmland characteristics are used to estimate marginal implicit prices of irrigation water in farmland under the Doroodzan dam.

The implicit price of any of the good's attributes can be determined by looking at how people are willing to pay for the good changes if this particular attribute changes. The schedule of prices of the good determined by market forces in any particular market can be summarized by a hedonic price function which is unique to that market, thereby reflecting the specific conditions of supply-and-demand at a specific locality (Latinopoulos et al. 2004). In this analysis, the implicit price of irrigation water was implied equally as WTP for one cubic meter of water for the farmer. Consequently, given the hedonic price function for land properties in an area, the implicit price of water can be determined by calculating the increase in the land value with an extra unit of this attribute.

In regression models, linear form, semi-log function form and $\log -\log$ form, and the implicit price of a variable $x$ is defined as:

$\partial p / \partial x_{k}=\beta_{k}$

$\partial p / \partial x_{k}=\beta_{k} p$

$\partial p / \partial x_{k}=\frac{\beta_{k}}{x_{k}} p$

That indicates the change of $p$ with an extra unit of attribute or variable $x$.

The two most important issues in the application of a HPM are the identification of the variables that represent the attributes of the agricultural property and the selection of the form of the hedonic price function (Garrod and Willis 1999).

In the present study, the hedonic model included important variables used in other related hedonic studies (Coelli et al. 1991; Elad et al. 1994; Veeman et al. 1994; Faux and Perry 1999; Leggett and Bockstael 2000; Latinopoulos et al. 2004; Pyykkönen 2005) and which were suitable for the conditions and situation of the study. The definition of dependent and independent variables in the applied model in the present study and the expected signs of the independent variables are presented in Table 1. The dependent variable in the applied model in the present study was the sale price of farmland ( $\$ /$ hectare). The independent variables were water quantity, water quality, water security, canal, size, available documents; build value, distance from the nearest road, crop yield, soil structure, and the slope of the land.

Economic theory is of no help in specifying a functional form for land use because it imposes no restrictions on the form of the hedonic price function (Palmquist 1984). It follows that the choice of such a form must be determined empirically and should be appropriately interpreted as an approximation of the true (but unknown) hedonic price function (Garrod and Willis 1999).

The case study presented herein refers to a rural region located under the Doroodzan dam in South-western Iran. It is a typical intensively irrigated region of the country that has recently had limited amounts if irrigation water.

The Doroodzan dam controls $>7,600$ million cubic meters of water per year, and provides irrigation water for 420,000 hectares of farmland. About $37 \%$ of farmland in 
Table 1 Definition of variables of hedonic model and expected signs with depended variable

\begin{tabular}{|c|c|c|c|}
\hline Variables & Definition & Expected signs & Unit \\
\hline Price & Price per hectare of cultivated land & & $(\mathrm{US} \$)$ \\
\hline Water quantity & Water quantity available for a hectare of farm land & + & $\left(\mathrm{m}^{3} / \mathrm{ha}\right)$ \\
\hline Water security & Farm land has directly access to irrigation water (canal and well) $(1=$ yes, $0=$ otherwise $)$ & + & \\
\hline Water quality & Quality of water $(1=$ drinkable water, $0=$ otherwise $)$ & + & \\
\hline Canal & Distance to canal & - & $(\mathrm{km})$ \\
\hline Size & Area of cultivated land & + & (ha) \\
\hline Document & Has document for land $(1=$ yes, $0=$ otherwise $)$ & + & \\
\hline Build value & Assessed value of buildings divided by total hectares & + & (US\$/ha) \\
\hline Road & Distance to the nearest paved road & - & $(\mathrm{km})$ \\
\hline Crop yield & Wheat yield in farm land & + & (US\$/ha) \\
\hline Soil structure & Soil quality $(1=$ class II, $0=$ otherwise $)$ & + & \\
\hline Slope & Indicates that topography of land is gently sloping $(1=$ yes, $0=$ otherwise $)$ & + & \\
\hline
\end{tabular}

this region uses canal water (water from the Doroodzan dam) whereas the remaining farmland uses groundwater for irrigation. The most important crops cultivated in the region are wheat, barely, maize, rice, sugar beet and tomato.

The survey was designed following the standard guidelines for a successful application of the HPM, and was put into practice using a questionnaire addressed to a sample of farmers having land in the area. Respondents (owners of farmland) were asked questions grouped according to four categories of elicited data: (a) demographic and social-economic (e.g., income, crop yield); (b) land structure, environs and location; (c) availability and methods of water supply and irrigation practice, as well as information about them; (d) information on land values, recent transactions and prices.

The survey was implemented with random sampling using personal interviews in the summer of 2008. This resulted in a sample of 243 complete questionnaires (observations). In addition, the validity and reliability of questionnaires were tested. However, the source of information for land value was one of our major concerns. The preferred way of estimating land values is including the sale price in actual market transactions, and these prices usually come from a real estate agency. Young (1996), North and Griffin (1993) stated that this would almost certainly lead to severe bias. In addition, there was not a real estate agency in the region of study, so we opted for self-reporting of land values by the owners and the subsequent confirmation by professional estate agency appraisers.

\section{Results}

After data collection, the hedonic model was built to determine the value of irrigation water. We used linear, semi-log and $\log -\log$ functional forms. The selection of the model was based on the Ramsey reset test (Gujarati 1995).

Ordinary least square (OLS) estimates of the three functional forms were applied. The linear functional form was the only one for which the $F$ value of the Ramsey reset test was not significant. The Ramsey reset test, being a general test of misspecification, thus supports the choice of the linear form.

After the estimate, all critical assumptions underlying the method of least squares were tested for the model (Gujarati 1995). Given the cross-sectional nature of our dataset, we tested for heteroskedasticity and rejected the null hypothesis of homoskedasticity. As such, we reported White's consistent standard errors in our regression results. In the present study, we used the condition index to identify multicollinearity by means of SPSS software. Condition index (CI) defined as (Gujarati 1995, page 338).

$\mathrm{CI}=\sqrt{\frac{\text { Maximum eigenvalue }}{\text { Minimum eigenvalue }}}$

Maximum and minimum eigenvalue for the model is 7.982 and 0.022 , respectively. So the condition index is 19.05 which is less than critical value (30).

Collinearity did not exist between the variables in the model. As shown in Table 2, in which OLS estimates are shown, all coefficients have the expected sign. The variables of size, water quality, build value, and soil structure had no effect on the sale price of land, but other variables had a significant effect on dependent variables.

The dummy variable (water security) indicated that farm land with access to irrigation water (canals and wells) increased the land price by nearly $\$ 11,310$ per hectare. If a farm had direct access to irrigation water (canals and wells), irrigation could occur throughout the season, and moisture was not a limiting factor to crop yields. Irrigation 
Table 2 The estimation result of hedonic mode

\begin{tabular}{llll}
\hline Variable & Coefficient & $t$ Statistic & $P$ value \\
\hline$c$ & $12,852^{\mathrm{a}}$ & 4.583918 & 0.000 \\
Canal & $-2,404^{\mathrm{a}}$ & -2.465840 & 0.010 \\
Document & $3,262^{\mathrm{a}}$ & 3.072751 & 0.005 \\
Road & $-194^{\mathrm{c}}$ & -2.174624 & 0.086 \\
Slope & $3,349^{\mathrm{b}}$ & 2.481141 & 0.014 \\
Water quantity & $0.046^{\mathrm{a}}$ & 2.532505 & 0.000 \\
Water security & $11,310^{\mathrm{a}}$ & 11.43426 & 0.000 \\
Crop yield & $1,697^{\mathrm{a}}$ & 4.658685 & 0.000 \\
Size & -15.9 & -0.186332 & 0.822 \\
Soil structure & 393 & 0.405113 & 0.696 \\
Build value & $0.0047^{\mathrm{c}}$ & 1.549238 & 0.054 \\
Water quality & 332 & 0.184268 & 0.848 \\
$n$ & 243 & & \\
F-statistics & 29.39 & & 0.000 \\
$R^{2}$ & 0.58 & & \\
$\bar{R}^{2}$ & 0.56 & &
\end{tabular}

${ }^{a}$ Statistical significance at the $1 \%$ level

b Statistical significance at the 5\% level

c Statistical significance at the $10 \%$ level

was particularly important for the profitability of the specialty crops grown in the irrigation districts which were the focus of the present study. Because of cultivation of two crops in one hectare per year in the area under study, the mean annual water consumption was estimated to be $37,000 \mathrm{~m}^{3} / \mathrm{ha}$. So by dividing 11,310 by average annual water consumption, the value of direct access to canal and well or the value of security of available water calculated is $\$ 0.306$ per cubic meter.

The economic meaning of the negative coefficient of the road (distance to the nearest paved road) was that a $1-\mathrm{km}$ increase in distance to the nearest paved road reduced the price per hectare by about $\$ 194$. Because access to some facilities (e.g., easy transportation), land situated near a paved road was more expensive than other land which had identical conditions except being near a paved road. Canals had a coefficient of $-2,404$, i.e., at the margin, an additional kilometer of canal reduced the value of the land per hectare by $\$ 2,404$. Farms with smaller canals or at a shorter distance from the major source of irrigation water commanded a higher price per hectare. The coefficient of documents indicates that the value of a hectare of land which had land documents was $\$ 3,262$ more than the value of a hectare of land which did not have land documents. The coefficient of slope showed the importance of leveling the land. This result implied that the value of each hectare of land which was well leveled or had a gentle slope was worth $\$ 3,349$ more than land that was not leveled. The variable that tried to capture the effect of differences in land quality (in addition to water) was the mean yield of the land. Production conditions vary considerably between farms and not all crops are suitable for the production, so the wheat yield was chosen to represent the yield potential. Wheat can be grown almost everywhere, and was the commonest crop in the region under investigation. Wheat yield was used as a proxy for land quality. An additional one ton wheat yield per hectare increased the value per hectare of land by $\$ 1,697$ (Table 2).

The most interesting variable was water quantity. This indicated the quantity of water from farms that had access to irrigation. The water quantity variable was also positive and highly significant. The coefficient of this variable could be interpreted as the implicit value of water in farms under the Doroodzan dam. The coefficient of water quantity variable estimated is 0.046 (Table 2). It means, one cubic meter extra water will increase the value of one hectare land $\$ 0.046$. Thus, the implicit price of irrigation water in the land investigated in the present study was $\$ 0.046$ per cubic meter. Given the hedonic price function for land properties in this area, the implicit price of water could be determined by calculating the increase in land value with an extra unit of this attribute. In the linear hedonic model, this price was the coefficient of the water variable.

\section{Discussion}

The price of one resource or good identifies its scarcity but the current price of irrigation water in our area of study did not reflect water scarcity. Determining the price of water which showed the true market value of it seemed appropriate. Based on the most important objective of the present study, it seemed necessary to price water according to its economic value. By accepting the real value of water, the incentive to conserve water and to use it optimally would be increased.

We found that water availability was the most important factor affecting on the price of farmland in the region of study. In addition of water quantity, land-structure characteristics (e.g., land slope, wheat crop) and neighborhood characteristics (e.g., distance from a paved road) had a significant effect on farmland prices. Based on the result from the hedonic model, the value of irrigation water in the region was estimated to be $\$ 0.046$ per cubic meter. This estimation compared well with reported values in applications of similar valuation methods (Tiwari 1998; Faux and Perry 1999; Latinopoulos et al. 2004). Some of the differences of water value in the mentioned studies may be due to the year of the estimation.

The estimated price for irrigation water was clearly higher than the price currently paid by farmers in the area of study. In the region of study, a large amount of water 
was used in agriculture for irrigation. The price charged to agricultural users typically does not reflect the marginal cost of supplying the water to them. Agricultural water supply is almost completely subsidized by a government program to assist agriculture production. That is, water price is very low or free; farmers therefore consume it readily. Among the basic principles of allocation of water resources are efficiency, equity and sustainability. It seems that in allocation of agricultural water in Iran, equity is the major criterion. Depletion and distortion result from inefficient pricing.

To use and save this vital agricultural input, farmers must be told of the real economic value of water in their area. Because of other goals in Iranian society (e.g., equality), obtaining the true price of water is very difficult. A "balanced price" that reflects water scarcity and provides an incentive for farmers to conserve water and use it more efficiently could be the best choice. Water pricing is one of the most important procedures for water resources sustainable development.

Informing farmers of the consequences of heavy consumption of water should be done gradually so that they can adapt their practices. Planning for application of this policy must be done with the contribution and cooperation of farmers.

Open Access This article is distributed under the terms of the Creative Commons Attribution License which permits any use, distribution and reproduction in any medium, provided the original author(s) and source are credited.

\section{References}

Abu-Madi MO (2009) Farm-level perspectives regarding irrigation water prices in the Tulkarm district, Palestine. Agric Water Manag 96:1344-1350

Birol E, Karousakis K, Koundouri P (2006) Using economic valuation techniques to inform water resource management: a survey and critical appraisal of available techniques and an application. Sci Total Environ 365:105-122

Coelli T, Lloyd-Smith J, Morrison D, Thous J (1991) Hedonic pricing for a cost benefit analysis of a public water supply scheme. Aust J Agric Econ 35:1-20

Doppler W, Salman AZ, Al-Karablieh EK, Wolff HP (2002) The impact of water price strategies on the allocation of irrigation water: the case of the Jordan Valley. Agric Water Manag 55:171-182

Elad RL, Clifton ID, Epperson JE (1994) Hedonic estimation applied to the farmland market in Georgia. J Agric Appl Econ 26:351-366

Faux J, Perry G (1999) Estimating irrigation water value using hedonic price analysis: a case study in Malheur County, Oregon. Land Econ 75:440-452
Feenberg D, Mills E (1980) Measuring the benefits of water pollution abatement. Academic Press, New York

Freeman R, Veeman TS (1993) Economic aspects of transferable water rights in Alberta, in water and the wilderness: development, stewardship, management. In: Manz D (ed) Proceedings of the 46th Annual Conference of the Canadian Water Resources Association 1993, pp 261-278

Garrod GD, Willis KG (1999) Economic valuation of the environment. Edward Elgar, Cheltenham

Gujarati DN (ed) (1995) Basic econometrics. McGraw-Hill, Singapore

Hartman LM, Anderson RL (1962) Estimating the value of irrigation water from farm sales in Northeastern Colorado. Farm Econ 44:207-213

Lancaster K (1966) A new approach to consumer theory. J Politi Econ 84:132-157

Latinopoulos P, Tziakas V, MallIos Z (2004) Valuation of irrigation water by the hedonic price method: a case study in Chalkidiki, Greece. Water Air Soil Pollut 4:253-262

Leggett CG, Bockstael NE (2000) Evidence of the effects of water quality on residential land prices. J Environ Econ Manag 39:121-144

Milliman JW (1959) Land values as measures of primary irrigation benefits. Farm Econ 41:234-243

North JH, Griffin CC (1993) Water source as a housing characteristic: hedonic property valuation and willingness to pay for water. Water Resour Res 29:1923-1929

Palmquist RB (1984) Estimating the demand for characteristics of housing. Rev Econ Statist 66:394-404

Poora PJ, Pessagnob KL, Paulc RW (2007) Exploring the hedonic value of ambient water quality: a local watershed-based study. Ecol Econ 60:797-806

Pyykkönen P (2005) Spatial analysis of factors affecting Finnish farmland prices. Paper prepared for presentation at the 99th seminar of the European Association of Agricultural Economists, The Future of Rural Europe in the Global Agri-Food System, Copenhagen, Denmark

Tarimo AKPR, Mdoe NS, Lutatina JM (1998) Irrigation water prices for farmer-managed irrigation systems in Tanzania: a case study of Lower Moshi irrigation scheme. Agric Water Manag 38:33-44

Tiwari DN (1998) Determining economic value of irrigation water. Working Paper GEC 98-05, CSERGE, University College London and University of East Anglia

Torell A, Libbin J, Miller M (1990) The market value of water in the Ogallala Aquifer. Land Econ 66:163-175

United Nations Environment Program (UNEP) (2005) Vital water statistics. http://www.unep.org/vitalwater/

Veeman TS, Veeman MM, Adamowicz WL, Royer S, Viney B, Freeman R, Baggs J (1994) Conserving water in irrigated agriculture: the economics and valuation of water rights. Project Report 97-01, Canada-Alberta Environmentally Sustainable Agriculture Research, Project No. RES 94-116, watershed-based study

Xu F, Mittelhammer RC, Torell LA (1994) Modeling non negativity via truncated logistic and normal distributions: an application to ranch land price analysis. J Agric Resour Econ 19:102-114

Young RA (1996) Measuring economic benefits for water investment and policies. World Bank Technical Paper No. 338. The World Bank, Washington DC

Young RA (2005) Nonmarket economic valuation for irrigation water policy decisions: some methodological issues. J Contemp Water Res Edu 134:21-25 